\title{
Tubifex tubifex chronic toxicity test using artificial sediment: methodological issues.
}

\author{
Arrate, Jesús Angel(1); Rodriguez, Pilar(1) and Martinez-Madrid, Maite(2) \\ (1)Dpto. Zoología y Biología Celular Animal, Facultad de Ciencias, Universidad del País Vasco, Apdo. 644 - \\ 48080 Bilbao. Spain. \\ (2)Dpto. Genética, Antropología y Fisiología Animal, Facultad de Ciencias, Universidad del País Vasco, \\ Apdo. 644 - 48080 Bilbao. Spain.
}

\begin{abstract}
The formulation and preparation of artificial sediments to be used in chronic toxicity tests is an important issue in the standardisation process. In the present study, artificial sediment has been used with Tubifex tubifex (Tubificidae, Oligochaeta) in both culture and in 28-day toxicity tests with spiked toxicants, in order to avoid the presence of occasionally important concentrations of some pollutants in sediments from apparently clean sites. The addition of supplementary food to the sediment at the beginning of the test is necessary to get satisfactory reproductive levels at the end of the 28-day chronic test, but this supplement of organic matter also provoked an additional increase of the levels of ammonia. The presence of ammonia at toxic levels in the artificial sediment during the first days after its preparation influences the quality of the water column and interstitial water, affecting the biological results of the test. The behaviour of the worms that escaped from sediment resulted in a reduction of their feeding activity, reproduction, and also mortality during the chronic test. Two different quantities of rations (80 and $160 \mathrm{mg}$ Tetramin ${ }^{\circledR}$ flakes) were compared, combined or not with a weekly renewal of the overlying water. The lowest peak of ammonia in water column and sediment pore-water was measured with $80 \mathrm{mg}$ of Tetramin ${ }^{\circledR}$. The weekly water renewal did not give better results in survival or reproduction at the end of the 28-day tests. A combination of sediment aeration during two weeks followed by a renewal of water column reduced the levels of ammonia in the water column and interstitial water below $1 \mathrm{mg} / \mathrm{N} \mathrm{N-N_{3 }}$. Therefore, this procedure is proposed for the reduction of ammonia, prior a toxicity test is conducted with artificial sediment, in order to avoid the presence of this compound at lethal or sublethal levels that could act as a confounding factor in chronic toxicity tests. The lowest supplement of food $(80 \mathrm{mg})$ in a static exposure regime was chosen as satisfactory for the chronic test. Survival percentage and reproduction (number of cocoons and number of young worms) were comparable with the data reported in tests with natural sediments using Tubifex tubifex, although both adult worm and cocoon biomass values were significantly lower and can not be used as end-points in toxicity tests with artificial sediment as it has been formulated here.
\end{abstract}

Keywords: Artificial sediment, un-ionised ammonia, confounding factors, aquatic oligochaetes

\section{RESUMEN}

La composición y preparación de sedimentos artificiales para su posterior utilización en test crónicos de toxicidad con sedimento es un elemento importante en el proceso de estandarización de este tipo de ensayos. En este estudio, el sedimento artificial ha sido utilizado en el cultivo de Tubifex tubifex (Tubificidae, Oligochaeta) y se ha puesto a punto para su utilización en test de toxicidad de 28 dias, para evitar la presencia de algunos contaminantes, ocasionalmente presentes en concentraciones importantes en sedimentos de localidades aparentemente limpias. Un suplemento de comida al inicio del test es necesario para que los gusanos alcancen niveles satisfactorios de reproducción a lo largo del test crónico de toxicidad de 28 días, pero dicho suplemento de materia orgánica contribuye a aumentar el nivel de amonio. La presencia de altas concentraciones de $\mathrm{N}-\mathrm{NH}_{3}$ durante los primeros días posteriores a la preparación del sedimento artificial puede reducir la calidad de la columna de agua y del agua intersticial y por lo tanto alterar los resultados biológicos. Los gusanos presentaban alteraciones en el comportamiento observándose una respuesta de escape, provocando una reducción de la actividad alimentaria y de la reproducción, y causando también mortalidad. Se compararon dos raciones suplementarias (80 y 160 mg Tetramin $\left.^{\circledR}\right)$, combinadas con un régimen estático o semiéstático de renovación semanal de la columna de agua. Los picos menores de $\mathrm{N}_{-} \mathrm{NH}_{3}$ fueron registrados con el suplemento de $80 \mathrm{mg}$ Tetramin ${ }^{\circledR}$. La renovación semanal de agua no produjo mejores resultados en supervivencia y reproducción de los gusanos al finalizar los 28 dias de duración del test. Una combinación de fuerte aireación del sedimento bajo agua durante dos semanas, seguido por la renovación de la columna de

Limnetica 23(1-2): 25-36 (2004). DOI: 10.23818/limn.23.03

(C) Asociación Ibérica de Limnología, Madrid. Spain. ISSN: 0213-8409 
agua al final de dicho periodo, redujo los niveles de $\mathrm{N}-\mathrm{NH}_{3}$ tanto en agua intersticial como en la columna de agua a valores inferiores a $1 \mathrm{mg} / \mathrm{l}$. Por lo tanto, se propone aplicar dicho procedimiento antes de iniciar un test crónico de toxicidad, y evitar la presencia de picos de $\mathrm{N}-\mathrm{NH}_{3}$ que puedan provocar efectos letales o subletales a los organismos y actuar como factor de confusión en los test que se realicen con sedimento artificial. Se propone la utilización de la dieta más baja (80 mg) y un régimen estático de exposición para el test de toxicidad con sedimento artificial. El porcentaje de supervivencia y los valores de las variables reproductivas (número de capullos y número de juveniles por adulto) resultaron comparables a los datos obtenidos en bioensayos con Tubifex tubifex en sedimento natural, aunque la biomasa final de los adultos y la de los capullos producidos resultan significativamente inferiores por lo que no se recomienda el uso de dichas variables en el test de toxicidad con sedimento artificial tal y como aqui se ha preparado.

Palabras clave: sedimento artificial, amonio no iónico, factores de confusión, oligoquetos acuáticos

\section{INTRODUCTION}

There is a wide range of types of natural sediments concerning their origin, the distribution of the particle size, as well as their organic content. It is also recognised that a particular natural sediment could not be available at a particular period of the year (Naylor \& Rodrigues 1995), or the possibility of alteration of its quality during sampling, transport or storage, as well as the presence of indigenous benthic fauna or trace pollutants that could modify the results of a sediment toxicity test (Burton 1992; Reynoldson et al. 1994).

Although it is difficult, if not impossible, to reproduce all properties of natural sediments, particularly those which affect the bioavailability of toxicants, artificial sediments can make easier the standardisation for comparison of ecotoxicity of different chemical compounds, or sensitivity of different species to a particular toxicant or mixture of toxicants spiked in the sediment (Harrahy \& Clements 1997). The use of artificial sediments seems also suitable when measuring levels of metals accumulated in a long-term exposure, since it is more and more difficult to find natural sediments unaffected by diffuse pollution. Natural sediments from apparently clean sites commonly present important levels of some metals that could alter the toxic response or the bioaccumulation processes by the test-organisms if they are used for culturing or/and they are used as a control batch in bioassays or for spiking toxicants in toxicity tests.

An artificial sediment simulates the physical and chemical characteristics of natural sediments and it should constitute a suitable habitat for the test organism, making possible its survival, growth and reproduction. During the last decade, several formulations have been proposed (Walsh et al. 1992; Suedel \& Rodgers 1994; Stephenson et al. 1994; Naylor \& Rodrigues 1995; Egeler et al. 1997; Ribeiro et al. 1999). Among them, the one proposed by Egeler et al. (1997) based on the OECD Guideline 207 (OECD 1984) for artificial soil is the most interesting for both culture and toxicity testing using the aquatic worm Tubifex tubifex (Oligochaeta, Tubificidae). This artificial sediment has satisfactorily been used in short-term static tests with tubificids (72 hours: Meller et al. 1998), and in bioaccumulation studies (6 or 12 days: Egeler et al. 1997; up to 12 days: Egeler et al. 1999; more than 60 days: Egeler et al. 2001).

The objective of the present study was to adjust the use of the artificial sediment proposed by Egeler et al. (1997) to the chronic bioassay of 28 days (Reynoldson et al. 1991) with Tubifex tubifex. Although it is not expected the artificial sediment to be as good as some natural sediment for the culturing of the species, it is possible to demonstrate that control conditions allow acceptable values for the test endpoints (Rodriguez \& Reynoldson 1999). One of the commonest confounding factors in artificial sediments is the high level of ammonia produced after the preparation of the formulated sediment that can cause lethal or sublethal effects in the test organisms. This factor is a consequence of both the organic components of the artificial sediment and the supplementary food, and it should be reduced to no-effect levels before the starting of the toxicity tests. 
Table 1. - Constituents of the artificial sediment as formulated by Egeler et al. (1997). Constituyentes del sedimento artificial según formulación propuesta por Egeler et al. (1997).

\begin{tabular}{ccc}
\hline Constituents & \% Sediment Dry Weight & Origin \\
\hline Peat & $2.0 \%$ & Sphagnum peat Floragard GmbH \\
Quartz sand & $76.0 \%$ & Fontainebleau Sand $(150-210 \mu \mathrm{m}$ particle size $($ Prolabo) \\
Kaolinite clay & $22.0 \%$ & Washed kaolin (Prolabo) \\
Calcium Carbonate & $0.1 \%$ & Powdered $\mathrm{CaCO}_{3}$ (Chemically pure, Panreac) \\
\hline
\end{tabular}

\section{MATERIAL AND METHODS}

\section{Preparation of the artificial sediment}

Table 1 shows the composition of the artificial sediment. Peat was air-dried in shallow plastic trays, and then sieved through $1 \mathrm{~mm} \varnothing$ mesh. A suspension of the peat is prepared using the required volume of deionised water (volume in $\mathrm{ml}=11.5 \mathrm{x}$ dry weight of peat), and homogenised using Ultraturrax T25 (IKA Labortechnik). Calcium carbonate was added to this suspension to adjust the $\mathrm{pH}(5.5 \pm 0.5)$, and it was kept at $22 \pm 1^{\circ} \mathrm{C}$ in the dark, for 48 hours, with slight stirring to allow the micro-organisms to establish. After this period, the peat suspension was mixed with the remaining constituents (sand and kaolinite clay) and deionised water added to sediment to get about $32 \%$ water content in a dry weight basis. Once prepared, the artificial sediment can be stored at $4^{\circ} \mathrm{C}$, in the dark, for several weeks.

\section{Culture}

Tubifex tubifex has been cultured in our laboratory at the University of the Basque Country for more than 10 years, from a population sampled at a small, permanent mountain stream (Saldropo, Gorbeia Natural Park, Vizcaya, Spain). Worms were cultured in artificial sediment placed in plastic containers of 15 (length) x 15 (width) x 7 (depth) $\mathrm{cm}$. To each container, $2 \mathrm{~cm}$-deep artificial sediment was added, $1 \mathrm{~g}$ Tetramin ${ }^{\circledR}$ as food supplement and ISO reconstituted water (ISO 1996). Cultures were organised in cohorts, started from 20 cocoons, and kept in the dark into a Sanyo MLR-350H incubator, at $22 \pm 1^{\circ} \mathrm{C}$, with a slight aeration. Water column was first replaced once a week, but this practice was unnecessary and afterwards water was only added to compensate the loss by evaporation. A few weeks before a toxicity test was run, a new supplement of Tetramin ${ }^{\circledR}$ was added to the water surface of culture batches in order to increase growth and induce the development of the clitella and gonads in worms.

\section{Experiment 1}

This experiment was designed to evaluate three questions related to the sediment toxicity test: first, the need of water column renewal along the test; second, the use of either de-chlorinated tap water or reconstituted water; third, the dose of supplementary food. Tubifex tubifex sediment bioassay (ASTM 1994) recommends a supplement of $80 \mathrm{mg}$ Tetramin ${ }^{\circledR}$ per test-unit, and we tested both 80 and $160 \mathrm{mg}$. The combination of two factors (replacement $v s$ not-replacement, and 80 vs $160 \mathrm{mg} \operatorname{Tetramin}^{\circledR}$ ) required a total of 24 test-units, with 3 replicates per condition. The experiment was duplicated using either de-chlorinated water $(D)$ or reconstituted water $(R)$ to test for possible differences in both ammonia concentration and worm survival and reproduction.

Each test unit consisted of 250-ml glass beakers filled with $50 \mathrm{ml}$ artificial sediment and $200 \mathrm{ml}$ reconstituted water with slight aeration which produced no or minimal re-suspension of the sediment. Into each beaker, four clitellated Tubifex tubifex worms, of the same age group, and in their first reproductive period were added. The initial biomass of the worms was calculated from a sub-sample of the worms extracted from the same culture batches used for the experiments. The duration of the experiment was 28 days. As control for physical and chemical vari- 
ables, a series of beakers with no worms were also filled with sediment and water, equivalent to each condition resulting of the combination of the two factors. In these beakers, $\mathrm{pH}$, dissolved oxygen and $\mathrm{N}-\mathrm{NH}_{3}$ were measured every week in the water column and $\mathrm{pH}$ in the sediment, using a Sentron $1001 \mathrm{pH}$ meter, WTW OXI-96 oxymeter, and a Hach model DR/200 spectrophotometer (Nessler method), respectively.

After 28 days, the sediment was sieved through $500 \mu \mathrm{m}$ and $100 \mu \mathrm{m}$ meshes. The number of living adults, the number of cocoons (both full and empty) and young worms were counted. The material obtained by the finest sieve was mainly composed by small young worms, and they were counted after fixation in ethanol $70 \%$. Adults were left in de-chlorinated tap water for 4 hours to purge their guts (Martinez-Madrid et al. 1999) and afterwards placed on washed, pre-weighted glassfiber Whatman ${ }^{\circledR}$ GC/F $25 \mathrm{~mm}$-filters, to calculate the final biomass of the worms $(B F)$. Full cocoons were also placed on Whatman filters to calculate their biomass. Approximately, 10 $\%$ filters were used as blank to correct the filter weight variations. Samples on the filters were dried into a Jouan EB500 oven, for 12 to 24 hours, and weighted on a Sartorius M3P precision balance (detection limit $1 \mu \mathrm{g}$ ).

Results were expressed as survival of adults (Surv), number of cocoons per adult (CcAd) and number of juveniles per adult ( $Y g A d)$. Hatching percentage was calculated as the percent of empty cocoons on the total number of cocoons. Somatic growth (Gsom) was calculated as the difference between final and mean initial adult biomass. Cocoon total biomass produced per adult $(C c B)$ was calculated as the product of the mean biomass of a single full cocoon by the total number of cocoons (empty and full) produced per adult. The individual cocoon biomass resulted from dividing the biomass of total un-hatched cocoons by the total number of un-hatched cocoons.

\section{Experiment 2}

The evolution of the ammonia concentration in the overlying water and in sediment pore-water was followed in this second experiment in order to establish whether it could attain lethal levels for the worms. Once the artificial sediment had been prepared, the $250-\mathrm{ml}$ beakers were filled with $50 \mathrm{ml}$ sediment and $200 \mathrm{ml}$ reconstituted water, as in experiment 1 , but in this case worms were not added. A supplement of $80 \mathrm{mg}$ Tetramin ${ }^{\circledR}$ flakes was added and manually mixed. Along the experiment, water was added to compensate the loss by evaporation. Beakers were kept for 28 days into an incubator at $22 \pm 1^{\circ} \mathrm{C}$, in the dark. Samples from the water column and interstitial water were taken and ammonia was measured by a Hach model DR/200 spectrophotometer (Nessler method). The extraction of sediment interstitial water was performed by sediment centrifugation $\left(3.500 \mathrm{rpm}, 4^{\circ} \mathrm{C}\right.$, 30 minutes) followed by filtration of the overlying water through a filter of $0.45 \mu \mathrm{m}$ mesh. In this experiment there were no replicates.

The same measurements were performed after a two-week oxidation period of the artificial sediment with a shallow water column, to allow the reduction of ammonia concentration. Once the artificial sediment had been prepared, it was left in a large-shallow tray (of about $1 \mathrm{~cm}$ depth of sediment) during 2 weeks, with water column under strong aeration at saturation, which favoured the loss of ammonia through its oxidation to nitrate. The water column was removed at the end of the 2-week period, the sediment was distributed into the test-beakers, and reconstituted water added (1:4 sediment:water). The characteristics of the water column $(\mathrm{pH}$, dissolved oxygen, conductivity, nitrates, nitrites, ammonia and phosphates) and the sediment pore-water ( $\mathrm{pH}$ and ammonia) were measured $48 \mathrm{~h}$ after the renewal of the water column, which corresponds to the moment that the test-organisms would be added to the test containers.

\section{Statistical analysis}

Data were tested for normality (KolmogorovSmirnov test) and homogeneity of variances (Barlett test) using the software ToxRat (Tox Rat Solutions GmgH 2002). Percentages were 
transformed to arcsine and, when necessary, reproduction or growth data were transformed to logarithms or square root for normalisation and homogeneity of the variances. Means of the variables were compared by the Student-t test or factorial ANOVA using the software Statview TM SE+ v.1.03 (Abacus concepts 1988) taking 0.05 as a significant level.

\section{RESULTS}

\section{Supplementary food, type of water and replacement of water column}

During the first week of experiment 1, worms were shown to leave the sediment and stayed at its surface during several days before going back into it. It was then suspected that this behaviour was an escape response to sediment pore-water loss of quality due to high levels of ammonia. Table 2 shows the weekly variation of $\mathrm{N}^{-\mathrm{NH}_{3}}$ concentration in the water column for treatments with (C) and without (S) weekly renewal of the water column. In those cases with no renewal of the water column, only two measurement of the $\mathrm{N}-\mathrm{NH}_{3}$ concentration are provided, at the beginning and at the end of the 28-day experiment. Ammonia in the water column showed an increase during the first week, being the concentration higher in those beakers with a food supplement of $160 \mathrm{mg}$ Tetramin ${ }^{\circledR}$, as it was expected. At the end of the second week, ammonia concentration was reduced to levels $\leq 2 \mathrm{mg} / 1 \mathrm{~N}-\mathrm{NH}_{3}$ and

Table 2.- Ammonia concentration $\left(\mathrm{N}-\mathrm{NH}_{3} \mathrm{mg} / \mathrm{l}\right)$, dissolved oxygen $\left(\mathrm{O}_{2} \mathrm{mg} / \mathrm{l}\right)$ and $\mathrm{pH}$ in the overlying water measured during experiment 1 (see text). D80: containers with de-chlorinated water and $80 \mathrm{mg}$ Tetramin ${ }^{\circledR}$; R80: containers with reconstituted water and $80 \mathrm{mg}$ Tetramin ${ }^{\circledR}$; D160: containers with dechlorinated water and $160 \mathrm{mg}$ Tetramin ${ }^{\circledR}$; R160: containers with reconstituted water and $160 \mathrm{mg}$ Tetramin ${ }^{\circledR}$; C: semi static exposure, with weekly water renewal; $\mathrm{S}$ : static exposure, without water renewal. Concentración de $\mathrm{N}_{-} \mathrm{NH}_{3}(\mathrm{mg} / \mathrm{l})$, oxigeno disuelto $\left(\mathrm{O}_{2}\right.$ mg/l) y pH en la columna de agua en el experimento 1 (ver texto). D80: Recipientes con agua declorada y 80 mg de Tetramin ${ }^{\circledR}$. R80: Recipientes con agua reconstituida y $80 \mathrm{mg}$ de Tetramin ${ }^{\circledR}$. D160: Recipientes con agua declorada y $160 \mathrm{mg}^{\text {de Tetramin }}{ }^{\circledR}$. R160: Recipientes con agua reconstituida y $160 \mathrm{mg}$ de Tetramin ${ }^{\circledR}$. C: exposición semiéstática, con cambio semanal de agua. S: exposición estática, sin cambio semanal de agua.

\begin{tabular}{|c|c|c|c|c|c|c|c|}
\hline & Day & 0 & $7 C$ & $14 C$ & $21 C$ & $28 C$ & $28 \mathrm{~S}$ \\
\hline \multirow{4}{*}{$\begin{array}{l}\mathrm{N}-\mathrm{NH}_{3} \\
\text { water column }\end{array}$} & D80 & 3.00 & 9.40 & 1.82 & 1.58 & 0.69 & 0.54 \\
\hline & R80 & 3.80 & 6.20 & 0.76 & 0.24 & 0.20 & 0.36 \\
\hline & D160 & 3.60 & 14.10 & 2.08 & 0.78 & 0.29 & 0.82 \\
\hline & R160 & 8.10 & 14.60 & 1.10 & 1.27 & 0.40 & 0.42 \\
\hline \multirow{4}{*}{$\begin{array}{l}\text { pH } \\
\text { water column }\end{array}$} & D80 & 7.52 & 7.66 & 7.95 & 7.59 & 7.48 & 7.97 \\
\hline & R80 & 7.55 & 7.69 & 7.85 & 7.42 & 7.41 & 7.83 \\
\hline & D160 & 7.56 & 7.79 & 7.78 & 7.58 & 7.83 & 8.04 \\
\hline & R160 & 7.55 & 7.70 & 7.86 & 7.51 & 7.50 & 7.98 \\
\hline \multirow{4}{*}{$\begin{array}{l}\mathrm{pH} \\
\text { sediment }\end{array}$} & D80 & 7.01 & 7.18 & 7.25 & 7.28 & 7.40 & 7.61 \\
\hline & R80 & 7.03 & 6.95 & 7.38 & 7.11 & 7.27 & 6.92 \\
\hline & D160 & 6.97 & 6.98 & 7.20 & 7.17 & 7.40 & 7.17 \\
\hline & R160 & 7.04 & 6.82 & 7.22 & 7.05 & 7.52 & 6.94 \\
\hline \multirow{4}{*}{$\mathrm{O}_{2}(\mathrm{mg} / \mathrm{l})$} & D80 & 7.01 & 6.50 & 8.0 & 8.14 & 8.40 & 8.46 \\
\hline & R80 & 8.35 & 8.82 & 8.12 & 8.22 & 8.45 & 8.40 \\
\hline & D160 & 6.80 & 6.98 & 8.40 & 8.25 & 8.44 & 8.41 \\
\hline & R160 & 8.20 & 7.45 & 8.36 & 7.99 & 8.43 & 8.40 \\
\hline
\end{tabular}


the tendency towards a reduction continued during the next two weeks. At the end of the 28 days, ammonia concentration in the water column had been notably reduced, below $1 \mathrm{mg} / \mathrm{l} \mathrm{N}-\mathrm{NH}_{3}$, independently of water column renewal. It is important to point out that fungi were observed at the sediment surface in beakers where high food supplement had been added. Dissolved oxygen and $\mathrm{pH}$ suffered slight changes along the experiment, but it seemed to be a tendency towards a $\mathrm{pH}$ increment in the water column along the experiment from about 7.5 up to 8.0. Sediment showed lower $\mathrm{pH}$ values than water column (Table 2).

In relation to the type of water used in the experiments, at the end of the 28-day period, those cases where reconstituted water had been used appeared to showed lower ammonia concentration in the water column, although statistical testing was not possible (Table 2). However, a Student ttest comparing mean values of $\%$ adult survival, number of cocoons per adult, number of young worms per adult, $\%$ hatching, biomass of total cocoons, and final adult biomass showed that there were not significant differences $(p>0.05)$ for these variables at each condition being tested (80C, 80S, 160C and 160S) (Table 3). Thus, data from experiments from the two water sources were pooled for statistical comparisons on the effects of different food supplements and water renewal regimes as explained below.

Adult mean mortality registered in experiment 1 ranged from 8.3 to $50 \%$. This high mortality in most of the studied conditions was interpreted as related to the anomalous escape behaviour of the

Table 3.- Mean and standard deviation of the biological variables measured at the end of experiment 1 using Tubifex tubifex, after 28 days in artificial sediment.

Abbreviations: D80: containers with dechlorinated water and $80 \mathrm{mg}$ Tetramin ${ }^{\circledR} ; R 80$ : containers with reconstituted water and $80 \mathrm{mg}$ Tetramin ${ }^{\circledR}$; D160: containers with dechlorinated water and $160 \mathrm{mg}$ Tetramin ${ }^{\circledR} ; R 160$ : containers with reconstituted water and $160 \mathrm{mg}$ Tetramin ${ }^{\circledR} ; C$ : semistatic exposure, with weekly water renewal; $S$ : static exposure, without water renewal). Surv: number of living adults out of 4 initial adults, $C c A d$ : number of cocoons per adult, $Y g A d$ : number of young worms per adult, \%Hatch: percentage of cocoon hatching, $C c B$ : Total biomas of cocoons (mg dw), Gsom: Somatic growth of adults (mg dw).

Media y desviación típica de las variables biológicas medidas al final del experimento 1 con Tubifex tubifex, transcurridos 28 días en sedimento artificial.

Abreviaturas: D80: Recipientes con agua declorada y $80 \mathrm{mg}$ de Tetramin ${ }^{\circledR}$. R80: Recipientes con agua reconstituida y 80 mg de Tetramin ${ }^{\circledR}$. D160: Recipientes con agua declorada y 160 mg de Tetramin ${ }^{\circledR}$. R160: Recipientes con agua reconstituida y 160 mg de Tetramin ${ }^{\circledR}$. C: exposición semiéstática, con cambio semanal de agua. S: exposición estática, sin cambio semanal de agua. Surv: Adultos supervivientes respecto a los 4 iniciales. CcAd: Capullos por adulto superviviente; JuAd: Juveniles por adulto superviviente; \%Hatch: Porcentaje de eclosión de los capullos; CcB: Biomasa total (mg peso seco) de los capullos; Gsom: Crecimiento somático (mg peso seco) de los adultos supervivientes.

\begin{tabular}{lcccccc}
\hline & Surv & CcAd & YgAd & \%Hatch & CcB & Gsom \\
\hline D80c & $3.7 \pm 0.6$ & $9.4 \pm 1.8$ & $18.7 \pm 9.1$ & $33.9 \pm 5.6$ & $0.389 \pm 0.057$ & $-0.092 \pm 0.066$ \\
$\boldsymbol{R} 80 \boldsymbol{c}$ & $3.0 \pm 1.0$ & $12.1 \pm 2.8$ & $16.3 \pm 3.9$ & $28.6 \pm 9.5$ & $0.472 \pm 0.209$ & $-0.010 \pm 0.247$ \\
D80s & $2.7 \pm 1.2$ & $11.4 \pm 6.6$ & $16.8 \pm 5.5$ & $34.8 \pm 5.1$ & $0.488 \pm 0.192$ & $-0.078 \pm 0.031$ \\
$\boldsymbol{R} 80 \boldsymbol{s}$ & $2.3 \pm 0.6$ & $11.4 \pm 1.0$ & $10.8 \pm 6.3$ & $27.0 \pm 9.2$ & $0.394 \pm 0.090$ & $-0.100 \pm 0.067$ \\
D160c & $2.0 \pm 1.0$ & $13.3 \pm 4.2$ & $16.2 \pm 9.6$ & $30.4 \pm 8.3$ & $0.430 \pm 0.175$ & $0.114 \pm 0.218$ \\
R160c & $3.3 \pm 1.2$ & $11.2 \pm 3.2$ & $9.6 \pm 1.9$ & $33.6 \pm 4.0$ & $0.565 \pm 0.094$ & $0.457 \pm 0.213$ \\
D160s & $2.7 \pm 0.6$ & $10.1 \pm 2.1$ & $14.7 \pm 8.7$ & $26.8 \pm 6.9$ & $0.354 \pm 0.078$ & $0.197 \pm 0.059$ \\
R160s & $2.3 \pm 1.5$ & $13.8 \pm 8.1$ & $19.2 \pm 12.7$ & $37.0 \pm 23.1$ & $0.508 \pm 0.260$ & $0.259 \pm 0.225$ \\
Natural sediment(I) & $3.9 \pm 0.2$ & $7.4 \pm 1.3$ & $16.3 \pm 10.3$ & $40.2 \pm 16.9$ & $0.691 \pm 0.188$ & $0.364 \pm 0.309$ \\
\hline
\end{tabular}

(1) Data from control batches in Martinez et al. (1999) 
organisms observed in the first days of the experiment, and probably associated to high levels of ammonia during the first week, although it was not clear when mortality had occurred along the experiment. A two-factor analysis of the variance was performed to find significant differences in the transformed variables (survival, growth or reproductive variables) being the two factors the supplementary food (80 and $160 \mathrm{mg}$ Tetramin ${ }^{\circledR}$ ) and the water-renewal regime (with and without weekly renewal). No significant differences of the mean values were found ( $F$ test, $p>0.05)$, except for final biomass of adults ( $\mathrm{F}_{\text {food supplement }}$ $=11.053, \mathrm{p}<0.003 ; \mathrm{F}_{\text {water renewal }}=1.916, \mathrm{p}=$ 0.182 , and $\mathrm{F}_{\text {interaction }}=0.923, \mathrm{p}=0.0034$ ). Somatic growth was negative for those worms fed on $80 \mathrm{mg}$ Tetramin ${ }^{\circledR}$ (mean $\pm \mathrm{sd}=-0.029 \pm$ $0.137 \mathrm{mg} \mathrm{dw}, \mathrm{n}=12$ ), but it was positive when fed on $160 \mathrm{mg}$ Tetramin $^{\circledR}($ mean $\pm \mathrm{sd}=0.257 \pm$ $0.210 \mathrm{mg} \mathrm{dw}, \mathrm{n}=12$ ) (Table 3).

\section{Ammonia concentration in the water column and in the sediment pore-water, in the absence of oligochaete worms}

In Experiment 2, $\mathrm{N}-\mathrm{NH}_{3}$ concentration in overlying water and sediment pore-water could be followed, in absence of worms. Sediment pore-water showed higher $\mathrm{N}-\mathrm{NH}_{3}$ concentration than water column (Fig. 1), although differences were not statistically tested due to lack of replicates. At the end of the first week, $\mathrm{N}-\mathrm{NH}_{3}$ levels increased in the pore-water and reached a maximum value of $20 \mathrm{mg} / \mathrm{l}$. The concentration was reduced to less than $5 \mathrm{mg} / 1$ at the end of the third week. In the water column, the maximum value was recorded during the second week, a few days after the maximum registered in the sediment porewater, but it did not exceed $15 \mathrm{mg} / 1 \mathrm{~N}-\mathrm{NH}_{3}$. Ammonia concentration was reduced rapidly, and at the end of the third week, the concentration was under $1 \mathrm{mg} / \mathrm{l}$.

A 2-week aeration period of the artificial sediment followed by water column renewal, was then conducted and as a result $\mathrm{N}-\mathrm{NH}_{3}$ concentration in the water column and pore-water

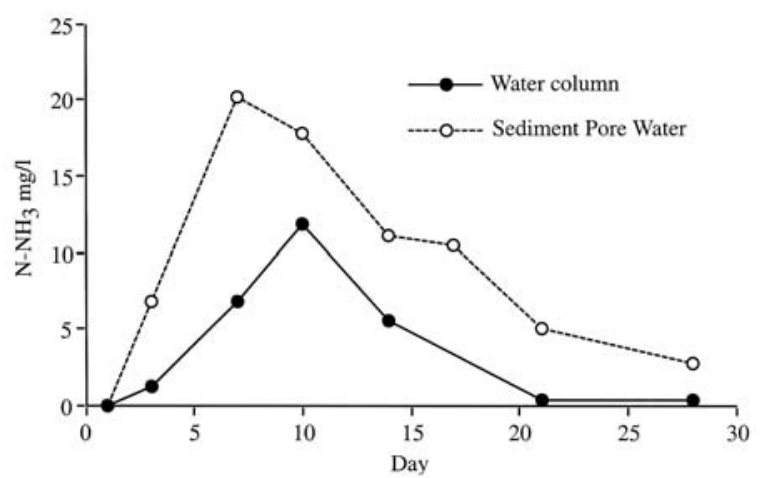

Figure 1.- Evolution of the $\mathrm{N}-\mathrm{NH}_{3}$ concentration (mg/l) in water column and sediment pore-water, in artificial sediment supplemented with $80 \mathrm{mg}$ Tetramin ${ }^{\circledR}$, in static exposure, without water renewal. Evolución de la concentración de $\mathrm{N}-\mathrm{NH}_{3}(\mathrm{mg} / \mathrm{l})$ en la columna de agua y en el agua intersticial en sedimento artificial con $80 \mathrm{mg}$ Tetramin $^{\circledR}$, en exposición estática sin cambio de la columna de agua.

was reduced below $1 \mathrm{mg} / \mathrm{l}$. The values of several chemical variables after this 2 -week period are shown in Table 4. Nitrates increased by the oxidation process but their concentration after removal of the water column was below the level considered to be dangerous for aquatic organisms. Values of 2-3 mg/ $\mathrm{NO}_{3}{ }^{-}$are considered to be normal in running waters and they can range in non-polluted waters between 1-15 mg/1 (Nisbet \& Verneaux, 1970).

Table 4.- Chemical characteristics of the water column and the sediment, two weeks after the preparation of the artificial sediment under aeration to reduce the ammonia concentration. DL: detection limit. Características químicas de la columna de agua y del sedimento, transcurridas dos semanas con aireación, para reducir los niveles de $\mathrm{N}-\mathrm{NH}_{3}$. DL: límite de detección.

$\begin{array}{lr}\text { Water column } & \\ \mathrm{pH} & 7.68 \\ \mathrm{O}_{2}(\mathrm{mg} / \mathrm{l}) & 8.00 \\ \text { Conductivity }(\mu \mathrm{S} / \mathrm{cm}) & 363.00 \\ \mathrm{PO}_{4}{ }^{3-}(\mathrm{mg} / \mathrm{l}) & 3.30 \\ \mathrm{NO}_{3}{ }^{-}(\mathrm{mg} / \mathrm{l}) & 1.76 \\ \mathrm{NO}_{2}{ }^{-}(\mathrm{mg} / \mathrm{l}) & <\mathrm{DL} \\ \mathrm{N}^{-\mathrm{NH}_{3}}(\mathrm{mg} / \mathrm{l}) & 0.22\end{array}$

\section{Sediment}

$\mathrm{pH}$ 7.22

$\mathrm{N}-\mathrm{NH}_{3}$ porewater $(\mathrm{mg} / \mathrm{l})$
0.40 


\section{DISCUSSION}

Optimisation of sediment test conditions is a complex process. Ankley et al. (1994) have summarised some of the most common problems of this type of studies and, among others, the authors discussed water-column renewal regime or the addition of supplementary food. These factors have been studied in the present work related to ammonia concentration, a variable that can become a confounding factor in artificial sediment tests, and may cause test failures due to low survival in the control batches. The natural processes of decomposition of the organic matter incorporated to the artificial sediment cause high levels of ammonia along the first days after its addition. The escape behaviour of the worms towards the sediment-water interface during the first week at experiment 1 could be explained by the increasingly higher levels of ammonia at the pore-water, compared with the water column. Whiteman et al. (1996) have also reported sediment-avoidance in sediment tests with the aquatic oligochaete Lumbriculus variegatus, when ammonia concentration in pore-waters was above $\mathrm{LC}_{50}$ values, because the corresponding water column concentration was much lower.

The toxicity of ammonia as a common pollutant in pore-waters of natural sediments has been evidenced by Ankley et al. (1990) in determining both acute and chronic toxicity to the fish Pimephales promelas and the daphnid Ceriodaphnia dubia. These authors proposed several techniques that either minimise the concentration of the toxic un-ionised ammonia (by control and manipulation of the $\mathrm{pH}$ ) or remove it by aeration or via cation exchange resins, such as zeolites. Sediment aeration and water column replacement for reducing ammonia concentration was proposed by EPA/USACE (Chapman, 1998). All these techniques have detractors when working with natural sediments since other toxic compounds can be altered or removed too. However, in formulated sediments aeration and $\mathrm{pH}$ control can be done before spiking the contaminants in the artificial sediment, avoiding ulterior interference.
It was clear from the evolution of ammonia concentration measured in the second experiment that ammonia reduction requires relatively long time periods in the context of actual duration of invertebrate toxicity tests. Thus, in the present work a two-week aeration period followed by water replacement is proposed for oxidation of ammonia and its reduction to acceptable levels for survival of benthic fauna. In our experience, a 2-week aeration period plus one water replacement was necessary to reduce ammonia concentration in the water column and sediment porewater below $1 \mathrm{mg} / \mathrm{l}$, at a $\mathrm{pH}$ of about 7.7. Monda et al. (1995) have reviewed the literature on acute toxicity of un-ionised ammonia for aquatic organisms and reported a range of values for 96-h $\mathrm{LC}_{50}$ of 1 to $10.2 \mathrm{mg} / 1 \mathrm{~N}-\mathrm{NH}_{3}$ for macroinvertebrate species. Our results can be explained by these data, since ammonia concentration can increase during the first days well above $10 \mathrm{mg} / \mathrm{l}$ in pore-waters and worms experiment escape behaviour; however, overlying water does not provide a safe habitat for worms since unionised ammonia also exceeded $10 \mathrm{mg} / 1$, causing worm mortality. The range of concentrations provided by Monda et al. persuaded us to reduce ammonia levels below $1 \mathrm{mg} / 1$ since it seems reasonable to work with lower values in a chronic exposure to avoid negative effects of ammonia on reproductive variables. In fact, low levels of ammonia can cause negative effects on reproduction. For instance, in 6-week chronic tests using the amphipod Hyalella, Borgmann (1994) found that reproduction was significantly reduced at a concentration of $0.32 \mathrm{mM} \mathrm{NH}_{3}$ $\left(=4.46 \mathrm{mg} / \mathrm{l} \mathrm{N}-\mathrm{NH}_{3}\right)$. In 4-week bioassays conducted after the present study, following the procedure described above for ammonia reduction, the behaviour of the worms was always normal, and in the few hours following the introduction of the worms into the test vessels, they excavated galleries and did not exhibit the escape behaviour. Worm mortality in the bioassay under control conditions was acceptably low $(<5 \%)$ (unpublished data) validating the chronic bioassays in artificial sediment. A semi-static weekly water renewal regime did not led to a 
higher reduction of ammonia in the water column in 28-day exposure, compared to those beakers with a static regime (see values for day $28 \mathrm{C}$ and $28 \mathrm{~S}$, in Table 2). However, differences have not been tested statistically due to the lack of replicates for chemical analysis.

The pH highly influences the toxicity of ammonia since in aqueous solution ammonium ions, ammonia and hydroxide ions are in equilibrium, being the toxicity dependent on the amount of un-ionised ammonia present and therefore dependent on $\mathrm{pH}$, as well (Hellawell, 1986). Schubauer-Berigan et al. (1995) examined the influence of $\mathrm{pH}$ in the ammonia toxicity on the aquatic oligochaete Lumbriculus variegatus in a 10-day aqueous test, under a through-flow regime, at $25^{\circ} \mathrm{C}$. That study showed that at a $\mathrm{pH}$ of 7.8 , that is similar to the $\mathrm{pH}$ in the water column in our experiments, a concentration of $24.0 \mathrm{mg} / 1 \mathrm{~N}-\mathrm{NH}_{3}$ causes $60 \%$ mortality of the exposed organisms, and no survival was reported at $34.6 \mathrm{mg} / 1 \mathrm{~N}-\mathrm{NH}_{3}$. Although the test species was different, those data help understanding the low survival data in our first experiment and the risk of exposing the test-organisms to the ammonia levels registered during the first two weeks after the preparation of the artificial sediment. Therefore, it is important not only the removal of ammonia, but also the $\mathrm{pH}$ control below 8 , to avoid the risk of toxicity due to high levels of un-ionised ammonia.

We did not find differences in the values of the endpoints using de-chlorinated tap water or reconstituted water. However, we decided to use reconstituted water in order to have higher standarisation in the toxicity test, as well as better comparison possibilities between metals and between tests in further experiments with metals measuring different end-points related to toxicity, bioaccumulation and biomarkers.

With respect to the addition of supplementary food to the test vessels, different authors have dissimilar positions. By one hand, the addition is not desirable since an excessive food supply could also cause loss of sensitivity of the testorganisms (Vecchi et al. 1999). By the other hand, Naylor \& Rodrigues (1995) found that chironomids could not survive in artificial sediment prepared with sand, clay and peat without the addition of supplementary food, although they stressed the risk of loss of water quality if food was in excess. In the present study, we describe the negative influence of the supplementary food in the ammonia concentration that could influence the existence of false positives in the toxicity tests. The poor nutritive value of the artificial sediment makes it necessary the addition of supplementary food in both cultures and toxicity tests to get acceptable reproduction levels. Growth parameters revealed that test conditions with the lowest ration $(80 \mathrm{mg}$ Tetramin ${ }^{\circledR}$ per test vessel) are not comparable to that in natural sediments (Table 3). MartinezMadrid et al. (1999) described loss of somatic biomass in worms associated to a high reproductive effort. However, in our experiments using artificial sediment the negative somatic growth of the adult worms and the lower biomass of the cocoons have been interpreted as probably due to the low nutritive value of the artificial sediment. Somatic growth showed comparable values when $160 \mathrm{mg}$ Tetramin ${ }^{\circledR}$ per vessel was added, however, higher ammonia levels and the presence of fungi persuaded us not to use this high diet in the toxicity tests. The possibility of using a supplement of $160 \mathrm{mg}$ Tetramin ${ }^{\circledR}$ in a chronic test followed by oxidation plus renewal of water column has not been checked. This diet could increase the values in the somatic growth of worms; however, the variability on Tetramin ${ }^{\circledR}$ composition makes the standardisation of bioassays more difficult (Egeler \& Römbke, 1999) as it can reduce interlaboratory comparability. For these reasons, we have decided to run the artificial sediment toxicity tests with the standard diet of $80 \mathrm{mg}$ Tetramin ${ }^{\circledR}$, even if this means that growth variables can not be included. Another important argument that favoured our decision for the lower diet was the possibility of working in static conditions, without water renewal. Metal concentration in sediment pore-water could be gradually reduced due to water renewal under semi-static exposure conditions. 
Finally, we can conclude that the use of artificial sediment in a sediment toxicity test based in the methodology proposed by Reynoldson et al. (1991) with the oligochaete worm Tubifex tubifex requires the following steps:

1. To avoid exposing the worms to high levels of ammonia in sediment toxicity tests that could cause mortality and false positives, sediment should be left for two weeks in a shallow tray covered by a water column under strong aeration, followed by the renewal of overlying water. This process favours ammonia reduction to levels below $1 \mathrm{mg} / \mathrm{l}$ in the water column and in the pore-water.

2. This process should be done before spiking metals for toxicity tests.

3. Low nutritional value at artificial sediment requires adding a food supplement.

4. The supplemented artificial sediment can be used in chronic toxicity tests of 28 days duration, under static conditions, only with replacement of the water loss due evaporation, using percent of survival and reproduction as end-points.

\section{ACKNOWLEDGEMENTS}

This work has been sponsored by the research project AMB1999/0440 (Ministerio de Ciencia y Tecnología, Spain).

\section{REFERENCES}

AMERICAN SOCIETY FOR TESTING AND MATERIALS. 1994. Standard guide for conducting sediment toxicity tests with freshwater invertebrates. ASTM E 1383-94, Philadelphia, pp: 24-30.

ANKLEY, G. T., A. KATKO \& J. ARTHUR. 1990. Identification of ammonia as an important sediment-associated toxicant in the Lower Fox River and Green Bay, Wisconsin. Environmental Toxicology and Chemistry, 9: 313-322.

ANKLEY, G. T., B. D. A. BENOIT, J. C. BALOGH, T. B. REYNOLDSON, K. E. DAY \& R. A. HOKE. 1994. Evaluation of potential confounding factors in sediment toxicity tests with three freshwater benthic invertebrates. Environmental Toxicology and Chemistry, 13 (4): 627-635.

BORGMANN, U. 1994. Chronic toxicity of ammonia to the amphipod Hyalella azteca; importance of ammonium ion and water hardness. Environmental Pollution, 86: 329-335.

BURTON G. A., Jr. 1992. Sediment collection and processing: factors affecting realism. In: Sediment Toxicity Assesment. Burton G.A. Jr. (ed).: 167182. Lewis Publ., Boca Raton.

CHAPMAN, P. M. 1998. Death by mud: Amphipod sediment toxicity tests. In: Microscale testing in aquatic toxicology. Advances, techniques, and practice. Wells P.G., Lee K. \& Ch. Blaise (eds): 451-463. CRC Press, Boca Raton.

EGELER, P. \& J. RÖMBKE (eds). 1999. Bioaccumulation: Sediment test using benthic oligochaetes. Proposal for a draft guideline according to OECD format. (unpublished material from a Workshop held in April 1999 in Hochheim/Main, Germany, organized by ECT Oekotoxikologie GmbH, Floerheim, Germany). 119 pp.

EGELER, P., J. RÖMBKE, M. MELLER, T. KNACKER, A. FRANKE, C. STUDINGER \& R. NAGEL. 1997. Bioaccumulation of lindane and hexachlorobenzene by tubificid sludgeworms (Oligochaeta) under standardised laboratory conditions. Chemosphere, 35(4): 835-852.

EGELER, P., J. ROMBKE, M. MELLER, T. KNACKER \& R. NAGEL. 1999. Bioaccumulation test with Tubificid Sludgeworms in artificial media-development of a standardisable method. Proceedings of the 7th International Symposium on Aquatic Oligochaetes, Presque Isle (B.M. Healy, T.B. Reynoldson \& K.A. Coates, eds). Hydrobiologia, 406: 271-280.

EGELER, P., M. MELLER, J. ROEMBKE, P. SPOERLEIN, B. STREIT \& R. NAGEL. 2001. Tubifex tubifex as a link in food chain transfer of hexachlorobenzene from contaminated sediment to fish. Proc. 8th International Symposium on Aquatic Oligochaeta, Bilbao (P. Rodriguez \& P.F.M. Verdonschot, eds). Hydrobiologia, 463: 171-184.

HARRAHY, E. A. \& W. H. CLEMENTS. 1997. Toxicity and bioaccumulation of a mixture of heavy metals Chironomus tentans (Dipetra: Chironomidae) in synthetic sediment. Environmental Toxicology and Chemistry, 16 (2): 317-327.

HELLAWELL, J. M. 1986. Biological indicators of freshwater pollution and environmental management. Elsevier Applied Science, London, 546 pp. 
ISO 6341: 1996(E). INTERNATIONAL STANDARD. 1996. Water Quality-Determination of the inhibition of the mobility of Daphnia magna Straus (Cladocera, Crustacea)-Acute Toxicity Test. 9 pp.

MARTINEZ-MADRID, M., P. RODRIGUEZ, J. I. PEREZ IGLESIAS \& E. NAVARRO. 1999. Sediment toxicity bioassays for assessment of contaminated sites in the Nervion River (Northern Spain). 2. Tubifex tubifex reproduction sediment bioassay. Ecotoxicology, 8: 111-124.

MELLER, M., P. EGELER, J.ROMBKE, H. SCHALLNAS, R. NAGEL \& B. STREIT. 1998. Short term toxicity of lindane, hexachlorobenzene, and copper sulfate to tubificid sludgeworms (Oligochaeta) in artificial media. Ecotoxicology and Environmental Safety, 39: 10-20.

MONDA, D. P., D. L. GALAT, S. E. FINGER \& M. S. KAISER. 1995. Acute toxicity of ammonia $\left(\mathrm{NH}_{3}-\mathrm{N}\right)$ in sewage effluent to Chironomus riparius. II. Using a generalized linear model. Archives of Environmental Contamination and Toxicology, 28: $385-390$.

NAYLOR, C. \& C. RODRIGUES. 1995. Development of a test method for Chironomus riparius using a formulated sediment. Chemosphere, 31 (5): 3291-3303.

NISBET, M. \& J. VERNEAUX. 1970. Composantes chimiques des eaux courantes. Discussion et proposition de classes en tant que bases d'interpretation des analyses chimiques. Annales de Limnologie, 6(2): 161-190.

OECD, 1984. Earthworm, acute toxicity tests. Guideline No. 207, Paris.

REYNOLDSON, T. B., S. P. THOMPSON \& J. L. BAMSEY. 1991. A sediment bioassay using the tubificid oligochaete worm Tubifex tubifex. Environmental Toxicology and Chemestry, 10: 1061-1072.

REYNOLDSON, T. B., K. E. DAY, C. CLARKE \& D. MILANI. 1994. Effects of indigenous animals on chronic endpoints in freshwater sediment toxicity tests. Environmental Toxicology and Chemestry, 13: 973-977.
RIBEIRO, R., L. A. KELLY, F. GONCALVES, G. A. BURTON \& A. M. V. SOARES. 1999. New artificial sediment for Chironomus riparius toxicity testing. Bulletin of Environmental Contamination and Toxicology, 63: 691-697.

RODRIGUEZ, P. \& T. REYNOLDSON. 1999. Laboratory Methods and Criteria for Sediment Bioassessment. Chapter 3. In: Manual of Bioassessment of Aquatic Sediments Quality. Lewis Publisher, Boca Raton: 83-133.

SCHUBAUER-BERIGAN, M. K., P. D. MONSON, C. W. WEST \& G. T. ANKLEY. 1995. Influence of $\mathrm{pH}$ on the toxicity of ammonia to Chironomus tentans and Lumbriculus variegatus. Environmental Toxicology and Chemistry, 14(4): 713-717.

STEPHENSON, G. L., K. E. DAY, R. SCROGGINS, R. SCOTT KIRBY \& P. HAMR. 1994. Current status of Environment Canada's Guidance on control of test precision using a spiked sediment toxicity test: What to spike and how? Environmental Toxicology and Risk Assesment: 4th Volume, STP.

SUEDEL, R. C. \& J. H. RODGERS. 1994. Development of formulated reference sediment for freshwater and estuarine sediment testing. Environmental Toxicology and Chemistry, 13 (7): 1163-1175.

VECCHI, M., T. B. REYNOLDSON, A. PASTERIS \& G. BONOMI. 1999. Toxicity of copper-spiked sediments to Tubifex tubifex (Oligochaeta, Tubificidae): Comparison of the 28-day reproductive bioassay with an early-life-stage bioassay. Environmental Toxicology and Chemistry, 18 (6): 1173-1179.

WALSH, G. E., D. E. WEBER, L. K. ESRY, M. T. NGUYEN, J. NOLES \& B. ALBRECHT. 1992. Synthetic substrata for propagation and testing of soil and sediment organisms. Pedobiologia, 36: 1-10.

WHITEMAN, F. W., G. T. ANKLEY, M. D. KAHL, D. M. RAU \& M. D. BALCER. 1996. Evaluation of interstitial water as a route of exposure for ammonia in sediment tests with benthic macroinvertebrates. Environmental Toxicology and Chemistry, 15(5): 794-801. 
